\title{
INVESTIGATION OF WORK-FAMILY AND FAMILY-WORK CONFLICTS AMONG SCHOOL TEACHERS FROM GENDER AND MARITAL STATUS PERSPECTIVE
}

\section{Bashir Hussain $^{1}$, Asia Zulfqar ${ }^{2 *}$, Nadia Gilani ${ }^{3}$, Syed Abdul Waheed ${ }^{4}$}

${ }^{1}$ Associate Professor, Department of Education, Bahauddin Zakariya University, Multan, Pakistan; ${ }^{2 *}$ Assistant Professor, Department of Education, Bahauddin Zakariya University, Multan, Pakistan; ${ }^{3}$ Assistant Professor, Department of Teacher Education, University of Okara, Okara, Pakistan; ${ }^{4}$ Assistant Professor, Department of Educational Research \& Assessment, University of Okara, Okara, Pakistan.

Email: ${ }^{1}$ bashirhussain@bzu.edu.pk, ${ }^{2 *}$ asia.zulfqar@bzu.edu.pk, ${ }^{3}$ nadia.gilani@uo.edu.pk, ${ }^{4}$ s.a.waheed@uo.edu.pk Article History: Received on $12^{\text {th }}$ June 2021, Revised on $19^{\text {th }}$ June 2021, Published on $21^{\text {st }}$ June 2021

\section{Abstract}

Purpose of the Study: The primary objective of this study was to investigate work-family and family-work conflicts and the nature of these conflicts among teachers in schools of Southern Punjab, Pakistan, from the perspective of their gender and marital status. Moreover, this research also examined the difference between work-family and family-work conflicts among teachers.

Methodology: This study used both descriptive and survey research designs. A questionnaire comprising 22-items work-family and family-work conflict scales was used. The researchers administered the tool to 422 elementary teachers from forty (40) schools of the three districts of southern Punjab, Pakistan, who were randomly selected using both multistage clusters and the stratified sampling techniques. Both descriptive and inferential statistics were employed for analyzing the data.

Main Findings: This study found that teachers hardly believe that their workplace tasks create hurdles in performing their family roles. Likewise, the study found that teachers hardly believe that their family responsibilities create any hurdles in performing their tasks at work. The study further found that female teachers' family is more affected by their work engagements than male.

Applications of this study: The results of this study will be helpful for teachers, counsellors, managers, and policymakers in developing programs that are likely to reduce work-family-work conflicts among teachers of elementary schools.

Novelty/Originality of this study: Work-family-work conflicts among teachers in schools of Southern Punjab, Pakistan, have not been addressed from the perspective of their gender and marital status.

Keywords: Work-family Conflicts, Family-work Conflicts, Gender and Marital Perspectives, Elementary School Teachers, Pakistan.

\section{INTRODUCTION}

The productive family patterns have led adult human lives to perform the two most important roles, i.e., the work and family roles. Consequently, both men and women have to play a dual role in the form of their responsibilities as workers and as a unit of a family (Abidin, 2017; Karimi, Jomehri, Asadzade \& Sohrabi, 2012; Nasir \& Lilianti, 2017). Each of these domains has unique roles and responsibilities attached to those roles. The literature demonstrates that these work and family roles influence each other in numerous ways (Ahmad, 2008; Barling \& Sorensen, 1997; Bellavia \& Frone, 2005; Brotheridge \& Lee, 2005; Özbağ, \& Ceyhun, 2014; Voydanoff, 2005; Zhou, Li, \& Gao, 2020). It has also led to numerous conflicts in the two roles of work and family (Anafarta, 2011; Ayo, Henry, \& Adebukola, 2009; Bellavia \& Frone, 2005; French, Dumani, Allen \& Shockley, 2018; Talukder, 2019). This has prompted researchers to investigate these two directional conflicts, i.e. work-family conflict and family-work conflict (Boloorizadeh, Tojari, \& Zargar, 2013; Bragger, Rodriguez-Srednicki, Kutcher, Indovino \& Rosner, 2005; Mete, Ünal \& Bilen, 2014). The researchers have further investigated how to work, and family domain variables are linked with various forms of conflicts (Nasir \& Lilianti, 2017; Odle-Dusseau, Britt, \& Greene-Shortridge, 2012; Talukder, 2019).

The research on work-family is primarily based on the role theory of Kahn, Worlfe, Quinn, Snock, and Rosenthal (1964), which suggested that individuals can go through conflicts in their work roles, family roles, and other roles. These sorts of multiple roles are likely to create inter-role conflicts among individuals because of conflicting demands of energy, time, or incompatible behaviours in their various roles (Kahn et al., 1964). The work-family conflicts are likely to occur when the demands from one role negatively affect individuals' potential to meet the demands that are linked with their role in some other domain (Greenhaus \& Beutell, 1985; Kremer, 2016; Mittal \& Bienstock, 2019). The literature demonstrates that the work-family-work conflict is bidirectional, as the work roles can affect individuals' responsibilities and roles in the family domain and vice-versa (Mesmer-Magnus \& Viswesvaran, 2005; $\underline{\text { Sanchez-Vidal, }}$ Cegarra-Leiva \& Cross, 2019). The work-family-work conflicts also refer to inter-role conflicts and create an imbalance among the work and the family roles (Kremer, 2016; Sanchez-Vidal et al., 2019; Furtado, Sobral \& Peci, 2016; Khandelwal \& Sehgal, 2018). Increased working hours, excessive time, heavy workloads, and massive efforts are the 
potential reasons for work-family conflict, which is likely to result in less amount of time, motivation, and energy to perform responsibilities in the family domain (Asbari et al., 2020; Greenhaus \& Beutell, 1985; Mete et al., 2014).

The family-work conflict occurs when the duties of the family negatively influence the role and responsibilities at the workplace (Bragger et al., 2005; Mete et al., 2014). The literature reveals that family-work conflicts are likely to create health problems, behavioural issues at the workplace, lack of efficiency, and non-compliance tasks at the workplace (Beauregard, 2006; Greenhaus \& Beutell, 1985; Peeters, Montgomery, Bakker \& Schaufeli, 2005). In summary, the work-family conflict happens when work results in the disturbance of family life, while family work conflicts are likely to occur when family impedes performance in the work environment (Greenhaus \& Beutell, 1989; Mete et al., 2014). Many researchers have conducted studies on different aspects of work-family-work conflict (Asbari et al., 2020; Mete et al., 2014), while limited studies exist in eastern countries (Nasurdin \& Hsia, 2008). Likewise, most work on the workfamily-work conflict has been conducted on professional workers but significantly less in the educational setting and on school teachers in the context of Pakistan. Similarly, the work the theme from the perspective of gender and marital status is scared. This research, therefore, investigates work-family and family-work conflicts among school teachers from a gender and marital status perspective in the schools of southern Punjab, Pakistan.

\section{LITERATURE REVIEW}

Human lives go through multiple roles. The two critical roles that adult human lives have to perform are their role at work and the family role. The literature also reveals that both men and women play a dual role in their responsibilities as workers and as a unit of a family (Abidin, 2017; Karimi, Jomehri, Asadzade \& Sohrabi, 2012; Nasir \& Lilianti, 2017). The literature further demonstrates that both work and family roles influence each other in numerous ways. It is further evident from research that work efficiency is more likely to be affected by family-related variables such as the number/age of children, support by the spouse, etc. Likewise, life at home is affected by work requirements (Greenhaus \& Beutell, 1985; Karimi et. al., 2012; Kossek \& Özeki, 2001). It has led to work-family-work conflicts. Studies conducted on the theme of work-family-work conflicts indicate mutual relationships between work and family (Karimi et al., 2012). Work is likely to disturb the family (work-family conflict), whereas family activities are likely to impede the work (family-work conflict). Both types of conflicts negatively affect work and family. For example, whereas workfamily conflicts mitigate satisfaction with married life, family-work conflict is likely to reduce satisfaction with the job (Erdamar \& Demirel, 2014).

Work and the family are two essential domains in an individual life. However, both the home tasks and job tasks affect each other correspondingly (Ajala, 2017; Cinamon \& Rich, 2005; Mesmer-Magnus \& Viswesvaran, 2005; SanchezVidal et al., 2019). In the same vein, Ghafoor, Ashraf, Sajjad, and Azeem (2014) highlights that these two domains are independent, but various scholars explored that such fields are interrelated and the relationship among variables is arising in the form of conflicts. As Greenhaus and Beutell (1985) view work-family conflict (WFC) as within-role conflict wherein the work demands and role in the family is contradictory in certain aspects. Consequently, participation in both family roles and work role is more complex because of the individuals' involvement in other roles. Likewise, Byron (2005) argued that WFC, also known as a work-family inference, which is within role conflict which arises when the roles in a family and the work demand conflict.

Conflicts generally increase the level of stress among individuals. It is evident from the literature that conflicts from work to family were significantly related to stress reactions (Cinamon \& Rich, 2005; Panatik, Badri, Rajab \& Yusof, 2012). The relationship between work and family is a construct measurement. The comprehensive demands associated with each of the roles are responsible, regulations, obligations, expectations, duties, and commitments with that role (Netemeyer, Maxham, \& Pullig, 2005). Work-family conflict arises when work creates particular difficulties in individuals' personal lives, dependent on its particularities. It may be rooted in the inflexible working timetable, long working days, and giving less time to family (Erdamar \& Demirel, 2014; Netemeyer et al., 2005). Allen, Herst, Bruck, and Sutton (2000) identified that work-family conflict negatively affects an individual and employing organizations. Karatepe and Kilic (2007) also argued that work-family conflicts affect working efficiency badly. It has an adverse effect on an efficient organization commitment indirectly way by working efficiency and job satisfaction. In the same way, many scholars found that job performance is the prime cause of work-family conflict; and found a negative relationship between job performance and work family-conflict (Bhuian, Menguc \& Borsboom, 2005; Karatepe and Sokmen, 2006; Netemeyer et al., 2005). The family life of individuals is affected by work demands (Greenhaus \& Beutell, 1985; Kossek \& Özeki, 2001).

Contrary to, with the interruption of family life by work, the family role may also create conflicts in the work role. For example, Erdamar and Demirel (2014) asserted that family might hinder professional life. For instance, Karatepe and Kilic (2007) argued that family-work conflicts affect working efficiency badly. The work-family conflicts minimize the happiness in married life, while family-work conflicts are likely to reduce job satisfaction (Ajala, 2017). The most common consequences of conflict between family and work are tiredness, poor performance, less skill and not being good at the work, job dissatisfaction, and quitting a job (Erdamar \& Demirel, 2014).

Many scholars found that work-family conflicts and family-work conflicts negatively affect each other, especially job performance (Allen et al., 2000; Karimi et al., 2012; Karatepe \& Sokmen, 2006). However, the most frequently observed 
conflicts under WFC regarding the teaching profession are persistent problems at home, opposition at work, mental and bodywork fatigue makes the family responsibility more challenging, and the job problem creates stress and tension at home (Erdamar \& Demirel, 2014). The other causes include bad performance, less occupational well-being, job disappointment, exhaustion, high intention to leave a job (Allen et al., 2000; Carlson \& Kacmar, 2000).

Teaching has been seen as a striking profession for females, but it demands loads of time and energy (Cinamon \& Rich, 2005). The teachers face more work-family conflict as compare to family-work conflict (Erdamar \& Demirel, 2014). However, there are many factors of the family-to-work conflict, such as Cinamon and Rich (2005) pointed that there may be two factors concerning conflict level and the direction are the experience of teachers and the age of their child. However, teachers' behaviours and their attitudes are affected by the family including spouse support, size of family, number of children, and their ages (Carlson \& Kacmar, 2000). Similarly, Erdamar and Demirel (2014) identified the potential causes of the family to work conflicts, and these include the lack of sleep due to home duties and tasks, child illness, family structure, and unexpected guest makes the professional life difficult.

Many studies have addressed the theme of work-family conflicts and family-to-work conflicts in different perspectives such as gender, age, marital status, and private and public schools. For example, Erdamar and Demirel (2014) and by Govender, Ramgoon, Patel, and Paruk (2006) found that female teachers face more work-family conflict than male teachers. In addition, Ahmad (2008) found that females who experience work-family conflict are also likely to experience emotional exhaustion. In respect of marital status, studies by Govender et al. (2006) and Chang (2002) concluded that married teachers are reported more family-work conflict in comparison with unmarried teachers. However, concerning age and institutes, the young private school teaches go through more work-family conflict than older and public-school teachers (Erdamar \& Demirel, 2014; Nginah, 2012). Likewise, Duxbury and Higgins (2003) found that the highly qualified workers cannot manage the balance between family and work due to the higher work commitment and, thus, are left with a very short time for their family.

In the context of Pakistan, Fatima and Sahibzada (2012) conducted a study on factors affecting the balance of work and family roles of a teacher. The factors are support from the spouse at home, issues of child care, the dependency of elders, and biased criticism at work sites. In addition, Mukarram, Akbar, Jan, and Gul (2012) found that work-family conflicts badly affect job performance. They also found that there are fewer policies for school teachers to address work-family conflicts, or it might be possible that there is a lack of awareness among teachers about such policies. In Pakistan, as a conservative society, Mukarram et al. (2012) asserted that many people still believe teaching is the most appropriate profession for females. Although, teaching is also creating some stress due to culture and religious norms, ineffective support, weak communication, and inefficient leadership. Furthermore, there are significantly few studies on workfamily-work conflicts among teachers at the school level. Likewise, the evidence lacks investigating work-family-work conflicts from the perspective of gender and marital status of teachers in schools of Southern Punjab, Pakistan. Similarly, it may be essential to examine the work-family and family-work conflicts to minimize stress and anxiety among teachers at the school level. This study is, therefore, focused on investigating the work-family-work conflicts and the nature of these conflicts among teachers in schools of Southern Punjab, Pakistan, from the perspective of their gender and marital status.

\section{RESEARCH QUESTIONS AND HYPOTHESES}

This study is focused on investigating the work-family-work conflicts and the nature of these conflicts among teachers in schools of Southern Punjab, Pakistan, from the perspective of their gender and marital status. Following research questions guided this study.

1. What is the nature of work-family-work conflicts among teachers in schools of Southern Punjab, Pakistan?

2. What is the difference between work-family and family-work conflicts among teachers in schools of Southern Punjab, Pakistan?

3. What is the difference between work-family and family-work conflicts among teachers in schools of Southern Punjab, Pakistan, from the perspective of their gender?

4. What is the difference between work-family and family-work conflicts among teachers in schools of Southern Punjab, Pakistan, from the perspective of their marital status?

In alignment with research questions, the following sets of hypotheses were stated to investigate work-family and familywork conflicts among teachers from the perspective of their gender and marital status:

1. Hypotheses $1\left(\mathrm{H}_{1}\right)$ : Teachers statistically significantly different in their work-family and family-work conflicts.

2. Hypotheses $2\left(\mathrm{H}_{2}\right)$ : Teachers statistically significantly differ by their gender in their work-family and family-work conflicts.

3. Hypotheses $3\left(\mathrm{H}_{3}\right)$ : Teachers statistically significantly differ by their marital status in their work-family and familywork conflicts. 
4. Hypotheses $4\left(\mathrm{H}_{4}\right)$ : Teachers statistically significantly differ by their gender and marital status in their work-familywork conflicts.

\section{METHODOLOGY}

\section{Design and Participants}

This study used both descriptive and survey research designs. It was delimited to elementary school teachers from three districts of Southern Punjab, Pakistan. So all elementary teachers from these three districts of Southern Punjab were taken as an accessible population. Of these three districts, forty schools were randomly selected. Of these forty, sixteen (16) schools were from Multan district and twelve (12) schools each from Khanewal and Muzaffargarh districts. Researchers sought consent from all elementary school teachers of these 40 randomly selected schools to participate in the study. On specific days of data collection, the research tool was distributed to all those teachers who have given their consent to participate in the study. The questionnaire was distributed to 541 teachers, who were available on days of data collection in these forty schools. Of these 541 teachers, 422 returned their questionnaires. So the return response rate of the tool was $78 \%$. As a result, all these 422 elementary teachers from forty (40) schools of three districts of southern Punjab, Pakistan, were taken as a sample for this study.

\section{Research Instrument}

For data collection, a questionnaire comprising work-family conflict and family-work conflict scales was used. This questionnaire was initially developed by Erdamar and Demirel (2014). This questionnaire comprised three parts. The first part of the questionnaire was designed to seek demographic information of the participants. The second part of the questionnaire consisting nine items designed on a five-point scale to seek information on the work-family conflict. The third part of the questionnaire comprised eleven items on a five-point scale to seek information on the family-work conflicts of the participants. The items of the five-point scale questionnaire were adopted from Erdamar and Demirel (2014).

The reliability of the nine items of the work-family conflict scale used by Erdamar and Demirel (2014) was 0.90. In contrast, the value of the Cronbach reliability coefficient for nine items of the work-family conflict scale used in this study was 0.78 . The reliability of the eleven items of the family-work conflict scale used by Erdamar and Demirel (2014) was 0.89 . The value of the Cronbach reliability coefficient for the eleven items of the work-family conflict scale used in this study was 0.80 . The overall value of the Cronbach reliability coefficient of the twenty items of the work-family conflict scale and the family-work conflict scale used in this study was 0.86 . This showed that both the overall tool, along with its parts, was highly reliable. The validity of the tool was ensured, as it was based on literature and covered both dimensions of the work-family conflict scale and family-work conflict scale as evident by Erdamar and Demirel (2014). The tool was further revisited by the experts in the context of Pakistan and was found valid. All 20 items of the tool were designed on the five-point scale, starting from strongly disagree to strongly agree.

\section{DATA ANALYSES}

To analyze data, descriptive statistics (mean, standard deviation) and inferential statistics (independent sample t-test) were used, using an updated version of the SPSS. In alignment with objectives, the results are being presented concerning the nature of work-family and family-work conflicts among teachers in schools of Southern Punjab, Pakistan, from the perspective of their gender and marital status.

\section{The Nature of Work-Family-Work Conflicts as Perceived by Teachers}

The results of the nature of the work-family conflicts as perceived by teachers are presented in Table 1, based on mean and standard deviations.

Table 1: The nature of work-family conflicts as perceived by teachers

\begin{tabular}{llll}
\hline S. No. & Themes based on statements & Mean & SD \\
\hline 1 & Tasks/responsibilities at work - unable to spend time with family. & 2.49 & 0.65 \\
\hline 2 & Fatigue at work - creates difficulties in home responsibilities. & 2.27 & 0.70 \\
\hline 3 & Fatigue at work - decreased tolerance towards family. & 2.39 & 0.76 \\
\hline 4 & Workplace duties cause tiredness while performing home tasks. & 2.36 & 0.81 \\
\hline 5 & Workplace tasks result in postponing house tasks. & 2.32 & 0.80 \\
\hline 6 & Workplace tasks reduce efforts for home responsibilities. & 2.32 & 0.87 \\
\hline 7 & Continuously think about workplace problems, affecting the family. & 2.64 & 1.10 \\
\hline 8 & Workplace problems cause stress and nervousness at home. & 2.39 & 0.92 \\
\hline 9 & Workplace duties/responsibilities get ahead of family. & 2.10 & 1.02 \\
\hline 10 & Overall & 2.37 & 0.85 \\
\hline
\end{tabular}

Table 1 clearly shows that the mean values of all nine statements about work-family conflicts is less than 3.00 , and range from 2.10 to 2.64. All these values show that elementary school teachers slightly disagreed with all nine statements and 
believe that their workplace activities hardly affect their family role. They hardly think that their tasks and responsibilities at the workplace create hurdles in spending time with their family. Likewise, they hardly believe that their physical and mental fatigue at the workplace causes any feelings of tiredness or creates difficulties in performing home responsibilities, or decreases their tolerance towards their family members. Teachers further believe that they spare time for their home tasks and family, and don't feel stress and nervous at home due to their work. Teachers are also of the view that their work-life hardly reduces their efforts for fulfilling their home responsibilities. Similarly, school teachers rarely believe that they are mainly thinking about their workplace problems while being at home or their workplace duties and responsibilities get ahead of their family life. The overall mean value of 2.37 also indicates that school teachers hardly believe that their workplace tasks create any sort of conflicts or hurdles in performing their family role. The standard deviation of 0.85 also indicates a good level of agreement among teachers regarding the rare existence of work-family conflicts. The results of the nature of the family-work conflicts as perceived by teachers are presented in Table 2, based on mean and standard deviations.

Table 2: The nature of family-work conflicts as perceived by teachers

\begin{tabular}{llll}
\hline S. No. & Themes & Mean & SD \\
\hline 1 & Home responsibilities reduce time/effort at work. & 2.51 & 0.60 \\
\hline 2 & Home responsibilities push jobs in the background. & 2.37 & 0.72 \\
\hline 3 & Home responsibilities cause deficiencies at work. & 2.52 & 0.74 \\
\hline 4 & Problems/troubles at home affect professional life. & 2.41 & 0.74 \\
\hline 5 & Home problems cause stress and nervousness at work. & 2.57 & 0.81 \\
\hline 6 & Continuously thinking about home problems affect work. & 2.47 & 0.79 \\
\hline 7 & Unexpected things at home (illness, guests, etc.) affect work. & 2.47 & 0.88 \\
\hline 8 & Home tasks reduce sleep time, affects work. & 2.46 & 0.91 \\
\hline 9 & Home responsibilities make me tired from work. & 2.43 & 0.88 \\
\hline 10 & Home responsibilities negatively affect my work activities. & 2.43 & 0.90 \\
\hline 11 & Home duties/responsibilities overtake work life. & 2.26 & 0.96 \\
\hline 12 & Overall & 2.45 & 0.81 \\
\hline
\end{tabular}

Table 2 clearly shows that the mean values of all eleven statements about family-work conflicts is less than 3.00 , and range from 2.26 to 2.57. All these values show that elementary school teachers slightly disagreed with all eleven statements and believe that their family activities hardly affect their activities at the workplace. Teachers hardly believe that their responsibilities at home reduce their time and effort at the workplace (Mean=2.51), or they need to put their jobs in the background (Mean=2.37) or create hurdles in job-related activities (Mean=2.43. It is also clear from Table 2 that teachers believe that their home responsibilities lead to deficiencies at their workplace $(\mathrm{Mean}=2.52)$. Teachers further believe that problems and troubles at home rarely affect their professional life in a negative way $($ Mean=2.41).

The results of Table 2 also indicate that teachers hardly believe that their problems at home or responsibilities make them either tired (Mean=2.43), stressed, or nervous (Mean=2.57) at the workplace tired. Similarly, school teachers rarely believe that they are mainly thinking about their home problems while working at the workplace $($ Mean=2.47) or their home responsibilities get ahead of their workplace duties (Mean=2.26). Table 2 also shows that teachers believe that unexpected events at home (such as illness in family/children, guests, etc.) rarely affect their performance at work (Mean=2.47). Teachers are further of the view that their household tasks reduce their sleeping time, which may create disturbance in work (Mean=2.46). The overall mean value of 2.45 also indicates that school teachers hardly believe that their responsibilities of the family create any sort of conflicts or hurdles in performing their tasks at work. The standard deviation of 0.81 also indicates a good level of agreement among teachers regarding the rare existence of family-work conflicts.

\section{Differences between Work-Family- and Family-Work Conflicts as Perceived by Teachers}

Table 3 presents the results of an independent sample t-test for examining the differences between work-family- and family-work conflicts of elementary school teachers.

Table 3: Differences between work-family- and family-work conflicts of teachers

\begin{tabular}{llllll}
\hline Nature of Conflicts & $\mathbf{N}$ & Mean & t & df & Sig. (2-tailed) \\
\cline { 1 - 3 } Work-family & 422 & 2.3655 & \multirow{2}{*}{-2.376} & \multirow{2}{*}{842} & \multirow{2}{*}{.018} \\
\hline Family-work & 422 & 2.4451 & & & \\
\hline
\end{tabular}

Table 3 clearly shows that the mean value of the family-work domain is greater than work-family conflicts, as perceived by teachers. Furthermore, a statistically significant difference ( $\mathrm{p}=.018 ; \mathrm{t}=-2.376)$ exists between both, and teachers believe that they face more family-work conflicts than work-family conflicts. It can be therefore concluded that teachers believe that their work is more affected by their family engagements than vice versa. Furthermore, the research hypothesis was accepted based on results. 


\section{Gender Differences about Work-Family- and Family-Work Conflicts as Perceived by Teachers}

Table 4 presents the results of an independent sample t-test for examining gender differences concerning work-familyand family-work conflicts of elementary school teachers.

Table 4: Gender differences between about work-family- and family-work conflicts

\begin{tabular}{|c|c|c|c|c|c|c|}
\hline Nature of Conflicts & Gender & $\mathbf{N}$ & Mean & $\mathbf{T}$ & df & Sig. (2-tailed) \\
\hline \multirow{2}{*}{ Work-family } & Males & 156 & 20.2949 & \multirow{2}{*}{-3.459} & \multirow[b]{2}{*}{420} & \multirow{2}{*}{.001 } \\
\hline & Females & 266 & 21.8722 & & & \\
\hline \multirow{2}{*}{ Family-work } & Males & 156 & 25.8718 & \multirow{2}{*}{-3.193} & \multirow{2}{*}{420} & \multirow{2}{*}{.002 } \\
\hline & Females & 266 & 27.4962 & & & \\
\hline \multirow{2}{*}{ Overall } & Males & 156 & 46.1667 & \multirow{2}{*}{-3.764} & \multirow{2}{*}{420} & \multirow{2}{*}{.000} \\
\hline & Females & 266 & 49.3684 & & & \\
\hline
\end{tabular}

Table 4 clearly shows that the mean value for female teachers is greater than male teachers in the work-family domain. Moreover, a statistically significant difference ( $\mathrm{p}=.001$; $\mathrm{t}=-3.459)$ exists between the two, and female teachers believe that they face more work-family conflicts than male teachers. It can be therefore concluded that female teachers believe that their family is more affected by their work engagements than male teachers. Moreover, the research hypothesis was accepted based on the results.

Table 4 clearly shows that the mean value for female teachers is greater than male teachers in the family-work domain. Moreover, a statistically significant difference ( $\mathrm{p}=.002 ; \mathrm{t}=-3.193)$ exists between the two, and female teachers believe that they face more family-work conflicts than male teachers. It can be therefore concluded that female teachers believe that their work is more affected by their family engagements than male teachers. It was also found that the research hypothesis was accepted based on the results.

In the overall comparison of both work-family- and family-work conflicts domains, table 4 clearly shows that the mean value for female teachers is greater than male teachers in both domains. Moreover, a statistically significant difference $(\mathrm{p}=.000 ; \mathrm{t}=-3.764)$ exists between the two, and female teachers believe that they face more work-family-work conflicts than male teachers. It can be therefore concluded that female teachers believe that their work is more affected by their family engagements than male teachers, and vice versa. Furthermore, the research hypothesis was accepted based on the results.

\section{Differences based on Marital Status about Work-Family- and Family-Work Conflicts as Perceived by Teachers}

Table 5 presents the results of an independent sample t-test for examining differences among teachers based on their marital status concerning work-family- and family-work conflicts.

Table 5: Marital status differences between about work-family-work conflicts

\begin{tabular}{lllllll}
\hline Nature of Conflicts & Marital Status & $\mathbf{n}$ & Mean & t & df & Sig. (2-tailed) \\
\hline \multirow{2}{*}{ Work-family } & Unmarried & 116 & 23.5862 & \multirow{2}{*}{6.663} & \multirow{2}{*}{420} & \multirow{2}{*}{.000} \\
\cline { 2 - 7 } Family-work & Married & 306 & 20.4183 & & & \\
\cline { 2 - 7 } & Unmarried & 116 & 23.8621 & -8.077 & \multirow{2}{*}{420} & \multirow{2}{*}{.000} \\
\hline \multirow{2}{*}{ Overall } & Married & 306 & 28.0458 & & & \\
\hline
\end{tabular}

Table 5 clearly shows that the mean value for unmarried teachers is greater than married teachers in the work-family domain. Furthermore, a statistically significant difference exists $(\mathrm{p}=.000 ; \mathrm{t}=6.663)$ between two, and unmarried teachers think that they face more work-family conflicts than married teachers. It can be therefore concluded that unmarried teachers believe that their family is more affected by their work engagements than married teachers. Moreover, the research hypothesis was accepted based on the results.

Table 5 also shows that the mean value for married teachers is greater than unmarried teachers in the family-work domain. Moreover, a statistically significant difference $(\mathrm{p}=.000 ; \mathrm{t}=-8.077)$ exists between the two, and married teachers believe that they face more family-work conflicts than unmarried teachers. It can be thus concluded that married teachers believe that their work is more affected by their family engagements than unmarried teachers. It was further found that the research hypothesis was accepted based on the results.

In the overall comparison of both work-family- and family-work conflicts domains, table 5 shows that the mean value for married teachers is greater than unmarried teachers in both domains. However, a statistically insignificant difference $(\mathrm{p}=.000 ; \mathrm{t}=-3.764)$ exists between the two, and there is no difference between married and unmarried teachers concerning work-family-work conflicts. Furthermore, the null hypothesis was accepted based on the results. 


\section{DISCUSSION}

This research found that school teachers hardly believe that their workplace tasks create any sort of conflicts or hurdles in performing their family role. Likewise, this research also found that school teachers hardly believe that their responsibilities of the family create any sort of conflicts or hurdles in performing their tasks at work. Moreover, there was a good level of agreement among teachers about the rare existence of work-family and family-work conflicts. These results are a bit in contradiction with literature which shows that both work and family roles influence each other (Ahmad, 2008; Barling \& Sorensen, 1997; Bellavia \& Frone, 2005; Brotheridge \& Lee, 2005; Özbağ, \& Ceyhun, 2014; Voydanoff, 2005; Zhou et al., \& Gao, 2020).

This study found that female teachers believe that their family is more affected by their work engagements than male teachers. Likewise, it was also found that unmarried teachers believe that their family is more affected by their work engagements than married teachers. Many researchers believe that these work-family conflicts are likely to occur when needs from one role negatively affect individuals' potential to meet the demands that are linked with their role in other domains (Greenhaus \& Beutell, 1985; Kremer, 2016; Mittal \& Bienstock, 2019). Increased working hours, excessive time, heavy workloads, and massive efforts are the potential reasons for work-family conflict, which is likely to result in less amount of time, motivation, and energy to perform responsibilities in the family domain (Asbari et al., 2020; Greenhaus \& Beutell, 1985; Mete et al., 2014).

This study found that female teachers believe that their work is more affected by their family engagements than male teachers, and vice versa. This research found that teachers believe that their work is more affected by their family engagements than vice versa. It was further found that female teachers think that their work is more affected by their family engagements than male teachers. Likewise, it was found that married teachers believe that their work is more affected by their family engagements than unmarried teachers. These forms of family-work conflict occur when the responsibilities of the family negatively influence the role and responsibilities at the workplace (Bragger et al., 2005; Mete et al., 2014). The literature reveals that family-work conflicts are likely to create health problems, behavioural issues at work, lack of efficiency, and non-compliance of tasks at the workplace (Beauregard, 2006; Greenhaus \& Beutell, 1985; Peeters et al., 2005).

\section{CONCLUSION}

In response to research questions, the following key conclusions were drawn based on the results. First, it was concluded that school teachers hardly believe that their workplace tasks create any sort of conflicts or hurdles in performing their family role. Results also indicated a good level of agreement among teachers regarding the rare existence of work-family conflicts. Second, it was concluded that school teachers hardly believe that their responsibilities of the family creates any sort of conflicts or hurdles in performing their tasks at work. Results also indicated a good level of agreement among teachers regarding the rare existence of family-work conflicts. Third, it was concluded that teachers believe that their work is more affected by their family engagements than vice versa. Fourth, it was concluded that female teachers believe that their family is more affected by their work engagements than male teachers.

Fifth, it was concluded that female teachers believe that their work is more affected by their family engagements than male teachers. Sixth, it was concluded that female teachers believe that their work is more affected by their family engagements than male teachers, and vice versa. Seventh, it was concluded that unmarried teachers significantly think that their family is more affected by their work engagements than married teachers. Finally, it was concluded that married teachers believe that their work-life is more affected by their family engagements than unmarried teachers.

\section{LIMITATIONS AND STUDY FORWARD}

This study employed a quantitative approach to investigate work-family-work conflicts among teachers from the perspective of their gender and marital status. The qualitative exploration of work-family-work conflicts may provide helpful insight for teachers, managers, counsellors, and policymakers. This research was delimited to the only publicsector elementary schools of three districts of Southern Punjab, Pakistan. The schools managed in private settings were not involved. The results of this study may be thus ideally generalized to elementary school teachers of southern Punjab. Further studies, however, may be conducted at a broader level and as well as in private settings. Likewise, comparative perspective work-family-work conflicts in public and private settings may provide valuable insight for stakeholders. Finally, further studies may be conducted on the causes and potential solutions of work-family-work conflicts among teachers.

\section{AUTHOR'S CONTRIBUTION}

All four authors contributed substantially for completion of this research article. The first and the second authors conceived the topic/idea for this research, explored the previous literature, and ensured data collection, and in the final write-up the article. The second and third authors conceive the idea of the research gap in area, contributed to the analysis of data and guided during interpretation of the results and in making discussion. They were also involved in the initial write-up of the article. The first two authors also concluded and reviewed whole paper as well as corresponded to publisher. The first two authors also worked in collaboration in most of the tasks of this paper. Overall, all four authors 
worked in collaboration with each other and consulted each other at each of the step, and, therefore, contributed significantly in this paper.

\section{REFERENCES}

1. Abidin, Z. (2017). Kesetaraan Gender dan Emansipasi Perempuan dalam Pendidikan Islam. Tarbawiyah Jurnal Ilmiah Pendidikan. 12(01), 1-17.

2. Ahmad, A. (2008). Direct and indirect effects of work-family conflict on job performance. The Journal of International Management Studies, 3(2), 176-180.

3. Ajala, E. M. (2017). Work-family-conflict and family-work-conflict as correlates of job performance among working mothers: implications for industrial social workers. African Journal of Social Work, 7(1), 52-62.

4. Allen, T. D., Herst, D. E., Burck, C. S., \& Sutton, M. (2000). Consequences associated with work to family conflict: A review and agenda for future research. Journal of Occupational Health Psychology, 5(1), 278-308. https://doi.org/10.1037/1076-8998.5.2.278

5. Anafarta, N. (2011). The relationship between work-family conflict and job satisfaction: A structural equation modeling (SEM) approach. International Journal of Business and Management, 6(4), 168-177. https://doi.org/10.5539/ijbm.v6n4p168

6. Asbari, I. B., Pramono, R., Hidayat, A., Alamsyah, P. S., \& Fayzhall, M. (2020). The Effect of work-Family conflict on Job Satisfaction and Performance: A Study of Indonesian Female Employees. International Journal of Advanced Science and Technology, 29(3), 6724-6748.

7. Ayo, H.T.; Henry, S. \& Adebukola, K. T. (2009). Psychosocial variables as predictors of work-family conflict among secondary school teachers in Irele local government area. Ondo State, Nigeria. Pakistan Journal of Social Sciences. 6(1), 11-18.

8. Abbas, F. \& Iqbal, Z. (2018). Language Attitude of the Pakistani Youth towards English, Urdu and Punjabi: A Comparative Study. Pakistan Journal of Distance and Online Learning, 4 (1), 199-214.

9. Barling, J. \& Sorenson, D. (1997). Work and family: In search of a relevant research agenda. In S. Jackson \& C.L. Cooper (Eds.) Creating tomorrow's organizations: A Handbook for future research in organizational behaviour (pp. 159-170). NY: Wiley.

10. Beauregard, T. A. (2006). Are organizations shooting themselves in the foot? Workplace contributors to familyto-work conflict. Equal Opportunities International, 25(5). https://doi.org/10.1108/02610150610706681

11. Bellavia, G., \& Frone, M. (2005). Work-family conflict. In J. Barling, E. K. Kelloway, and M. Frone (Eds.), Handbook of Work Stress, (pp. 113-147). Sage Publications: Thousand Oaks. https://doi.org/10.4135 19781412975995.n6

12. Bhatti, A.M., Abbas, F. \& Rana, A.M.K. (2020). An Empirical study of learning styles used by undergraduate English learners in public sector colleges in Pakistan. Elementary Education Online, 19 (3), 1864-1875.

13. Bhuian, S. N., Menguc, B., \& Borsboom, R. (2005). Stressors and job outcomes in sales: A triphasic model versus a linear-quadratic-interactive model. Journal of business research, 58(2), 141-150. https://doi.org/10.1 016/S0148-2963(03)00132-2

14. Boloorizadeh, P., Tojari, F., \& Zargar, T. (2013). Work-family conflict among female head coaches in Iran. Procedia-Social and Behavioral Sciences, 84(1), 1403-1410. https://doi.org/10.1016/j.sbspro.2013.06.764

15. Bragger, J. D., Rodriguez-Srednicki, O., Kutcher, E. J., Indovino, L., \& Rosner, E. (2005). Work-family conflict, work-family culture, and organizational citizenship behavior among teachers. Journal of Business and psychology, 20(2), 303-324. https://doi.org/10.1007/s10869-005-8266-0

16. Brotheridge, C. \& Lee, R. (2005). Impact of work-family interference on general well-being: Replication and extension. International Journal of Stress Management, 12(1), 203-221. https://doi.org/10.1037/10725245.12.3.203

17. Byron, K. (2005). A meta-analytic review of work-family conflict and its antecedents. Journal of vocational behavior, 67(2), 169-198. https://doi.org/10.1016/j.jvb.2004.08.009

18. Carlson, D. S., \& Kacmar, K. M. (2000). Work-family conflict in the organization: Do live role values make a differences? Journal of Management, 26(1), 1031-1054. https://doi.org/10.1177/014920630002600502

19. Chang, K. M. (2002). The influences of work-family conflict and sex-role identity on married female teacher's job involvement. International Journal of Human Ecology, 3(1), 95-109.

20. Cinamon, R. G., \& Rich, Y. (2005). Work-family conflict among female teachers. Teaching and teacher education, 21(4), 365-378. https://doi.org/10.1016/j.tate.2004.06.009

21. Duxbury, L., \& Higgins, C. (2003). Work-life conflict in Canada in the new millennium. The Sydney Papers, 15(1), 78-97.

22. Erdamar, G., \& Demirel, H. (2014). Investigation of work-family, family-work conflict of the teachers. Procedia-Social and Behavioral Sciences, 116(1), 4919-4924. https://doi.org/10.1016/j.sbspro.2014.01.1050

23. Fatima, N., \& Sahibzada, S. A. (2012). An empirical analysis of factors affecting work life balance among university teachers: the case of Pakistan. Journal of International Academic Research, 12(1), 16-29.

24. French, K. A., Dumani, S., Allen, T. D., \& Shockley, K. M. (2018). A meta-analysis of work-family conflict and social support. Psychological bulletin, 144(3), 284. https://doi.org/10.1037/bul0000120 
25. Furtado, L., Sobral, F. \& Peci, A. (2016). Linking demands to work-family conflict through boundary strength. Journal of Managerial Psychology. 31(8), 1327-1342. https://doi.org/10.1108/JMP-11-2015-0408

26. Ghafoor, M., Ashraf, A., Sajjad, I., \& Azeem, M. (2014). Antecedents and consequences of work family conflicts. European Journal of Business and Management, 6(4), 153-160.

27. Govender, V., Ramgoon, S., Patel, C. J., \& Paruk, Z. (2006). Working mothers: Family-work conflict, job performance and family/work variables. SA Journal of Industrial Psychology, 32(2), 39-45. https://doi.org/1 0.4102/sajip.v32i2.238

28. Greenhaus, J. H., \& Beutell, N. J. (1985). Sources of conflict between work and family roles. Academy of management review, 10(1), 76-88. https://doi.org/10.5465/amr.1985.4277352

29. Iqbal, A. Ali, M.S., Abbas, F Shah, M.A.H. \& Anjum, S. (2020). A Study of Work-Family Conflict among Elementary School Teachers. International Journal of Innovation, Creativity and Change. 14 (10), 198-209.

30. Kahn, R. L., Wolfe, D.M., Quinn R., Snoek, J.D. \& Rosenthal R.A. (1964). Organizational stress: studies in role conflict and ambiguity, Wiley, New York.

31. Karatepe, O. M., \& Kilic, H. (2007). Relationships of supervisor support and conflicts in the work-family interface with the selected job outcomes of frontline employees. Tourism management, 28(1), 238-252. https://doi.org/10.1016/j.tourman.2005.12.019

32. Karatepe, O. M., \& Sokmen A. (2006). The effects of work role and family role variables on psychological and behavioral outcomes of frontline employees. Tourtsm Management, 27(2), 255-268. https://doi.org/10 .1016/j.tourman.2004.10.001

33. Karimi, Q., Jomehri, F., Asadzade, H., \& Sohrabi, F. (2012). Consequences of conflict between work and family among Iranian female teachers. Journal of Basic Applied Science Research, 2(2), 1869-1875.

34. Khandelwal, P., \& Sehgal, A. (2018). Exploring work-family interface for Indian women entrepreneurs, Gender in Management. 33(3), 203-216. https://doi.org/10.1108/GM-04-2016-0075

35. Kossek, E. E. \& Ozcki, C. (2001). Work-family conflict, policies, and the job-life satisfaction relationship: a review and directions for organizational behavior-human resources research. Journal of Applied Psychology, 83(2), 139-149. https://doi.org/10.1037/0021-9010.83.2.139

36. Kremer, I. (2016). The relationship between school-work-family-conflict, subjective stress, and burnout, Journal of Managerial Psychology, 31(4), 805-819. https://doi.org/10.1108/JMP-01-2015-0014

37. Mesmer-Magnus, J., \& Viswesvaran, C. (2005). Convergence between measures of work-to family and familyto-work conflict: A meta-analytic examination. Journal of Vocational Behavior, 67(1), 215-232. https://doi.org /10.1016/j.jvb.2004.05.004

38. Mete, M., Ünal, Ö. F., \& Bilen, A. (2014). Impact of work-family conflict and burnout on performance of accounting professionals. Procedia-Social and Behavioral Sciences, 131(1), 264-270. https://doi.org/10.1016/j.sbspro.2014.04.115

39. Mittal, R. \& Bienstock, J. (2019). Transformational leadership and polychronicity as antecedents of work-home boundaries, Management Research Review, 42(4), 460-468. https://doi.org/10.1108/MRR-02-2018-0093

40. Mukarram, A., Akbar, S., Jan, Z., \& Gul, A. (2012). Work-life conflict impact on female's job performance: A study of primary level female school teachers in Pakistan. European Journal of Business and Management, 4(20), 74-83.

41. Nasir, \& Lilianti (2017). Persamaan Hak: Partisipasi Wanita dalam Pendidikan. Didaktis: Jurnal Pendidikan dan Ilmu Pengetahuan. 17(1), 36-46.

42. Nasurdin, A. M.; Hsia, K. L. (2008). The influence of support at work and home on work-family conflict: does gender make a difference?, Research and Practice in Human Resource Management, 16(1), 18-38.

43. Netemeyer, R. G., Maxham, J. G., \& Pullig, C. (2005). Conflicts in the work-family interface: Links to job stress, customer service employee performance, and customer purchase intent. Journal of Marketing, 69(1), 130-143. https://doi.org/10.1509/jmkg.69.2.130.60758

44. Nginah, N. M. (2012). Influence of work-family conflicts on secondary school teachers' level of job satisfaction in Machakos District, Kenya (Unpublished Master's Thesis). Department of Educational Administration, University of Nairobi, Nairobi, Kenya.

45. Odle-Dusseau, H. N., Britt, T. W., \& Greene-Shortridge, T. M. (2012). Organizational work-family resources as predictors of job performance and attitudes: The process of work-family conflict and enrichment. Journal of occupational health psychology, 17(1), 28. https://doi.org/10.1037/a0026428

46. Özbağ, G. K., \& Ceyhun, G. Ç. (2014). Does job satisfaction mediate the relationship between Work-family conflict and turnover? A study of Turkish marine pilots. Procedia-Social and Behavioral Sciences, 140(1), 643649. https://doi.org/10.1016/j.sbspro.2014.04.485

47. Panatik, S. A. B., Badri, S. K. B. Z., Rajab, A. B., \& Yusof, R. B. M. (2012). Work-family conflict and workrelated attitude: the mediating effects of stress reactions. International Journal of Social Sciences and Humanity Studies, 4(1), 377-387.

48. Peeters, M.C.W., Montgomery, A.J., Bakker, A.B., \& Schaufeli, W.B. (2005). Balancing work and home: How job and home demands are related to burnout. International Journal of Stress Management, 12(1), 43-61. https://doi.org/10.1037/1072-5245.12.1.43 
49. Sánchez-Vidal, M., Cegarra-Leiva, D. \& Cross, C. (2019). Gender differences in inter-role conflict in Spain. Employee Relations. 42(2), 437-452. https://doi.org/10.1108/ER-02-2019-0120

50. Talukder, A. M. H. (2019). Supervisor support and organizational commitment: The role of work-family conflict, job satisfaction, and work-life balance. Journal of Employment Counseling, 56(3), 98-116. https://doi.org/10.1002/joec.12125

51. Voydanoff, P. (2005). Work Demands and Work-to-Family and Family-to-Work Conflict: Direct and Indirect Relationships, Journal of Family Issues, 26(1), 840-865. https://doi.org/10.1177/0192513X05277516

52. Zhou, S., Li, X., \& Gao, B. (2020). Family/friends support, work-family conflict, organizational commitment, and turnover intention in young preschool teachers in China: A serial mediation model. Children and youth services review, 113(1), 104997. https://doi.org/10.1016/j.childyouth.2020.104997 